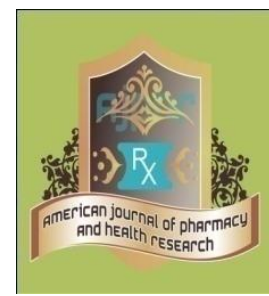

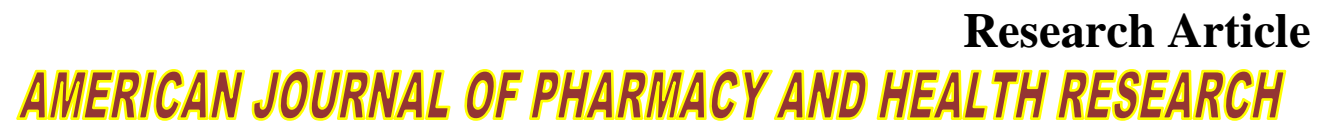
www.ajphr.com 2020, Volume 8, Issue 4 ISSN: 2321-3647(online)

\title{
Efficacy of Unani combo therapy (Hab-e-Surfa and Sharbat-e- Unab) in the management of Upper respiratory troubles
}

\author{
Irfat Ara $^{1}$, Basharat Bukhari ${ }^{1}$, Nighat Ara ${ }^{1}$ \\ 1.Regional Research Institute Of Unani Medicine, University of Kashmir
}

\begin{abstract}
To determine the efficacy and tolerability of Unani drug preparations Hab-e-Surfa and Sharbat-eUnab, we conducted the open labeled, non-comparative clinical trial focused on the patients of either sex in the age group between 14 to 60 years with upper respiratory disorders at Regional Research Institute of Unani medicine, University of Kashmir Srinagar from September 2012September 2015 irrespective of socio economic status. After baseline assessment, a total number of 60 patients with upper respiratory tract disorders were treated with Hab-e-Surfa with the dose of 2 Tabs (Hab) twice a day and Sharbat-e- Unab 2 tsf twice a day for one week. Clinical assessment of disease were assessed at baseline and after treatment. The pre and post treatment score was compared statistically and recorded. From the result it was observed that Hab-e-Surfa and Sharbat-e- Unab significantly reduced all the signs and symptoms of upper respiratory tract troubles after one week treatment. No adverse effect has been noticed during the study period. Hence it is concluded that Hab-e-Surfa and Sharbat-e-Unab acts as expectorant, lubricant ,concoctive, coolant, sedative, febrifuge, demulcent and is a promising Unani herbal preparation which is effective and safe.
\end{abstract}

Keywords: Sual, Clinical trial, Unani Medicine, Unab, Kashmir.

*Corresponding Author Email: drirfat@yahoo.com

Received 10 April 2020, Accepted 21 April 2020

Please cite this article as: Ara I et al., Efficacy of Unani combo therapy (Hab-e-Surfa and Sharbat-e-Unab) in the management of Upper respiratory troubles. American Journal of Pharmacy \& Health Research 2020. 


\section{INTRODUCTION}

Respiratory tract infections continue to be a major health challenge worldwide especially due to pollution and the increasingly fast development of resistance to the drugs currently in use. In Kashmir it is common due to its remoteness, cold and harsh climatic conditions as well as limited health care facilities. The respiratory tract infections are illnesses caused by an acute infection which involves respiratory tract including the nose, sinuses, pharynx or larynx, lungs etc. These structures direct the air, we breathe from outside to the trachea and eventually to the lungs for respiration to take place. This process warms the inspired air and filters out small particles of dust and injurious bacteria. In health it is a normal habitat of various organisms, in disease the mucous membrane often becomes the site of an air borne infections (E.C.Warner1996).

Respiratory tract infections commonly includes nasal obstruction, sore throat, tonsillitis, pharyngitis, laryngitis, common cold, cough etc. Most infections are viral in nature and in other instances the cause is bacterial. Cough is common, persistent symptom of many acute and chronic diseases. It results from irritation due to infection, inflammation, tumour or foreign body and may also be due to the irritation of cough receptors located in the pharynx and bronchi. It is a natural reflex expulsive defence mechanism in the body for the respiratory tract and is usually dry, but may be moist and accompanied by sputum where there is irritation of the bronchus (E.C.Warner1996). It is a common complaint in clinical practice. cough is one of the symptom associated with sore throat, hoarseness of voice, nose block, breathlessness, heart burn, chest pain, dizziness, insomnia, urinary incontinence, heamoptysis, lack of concentration, vomiting and also produce blood stained phalgum (Janson C et al1991). Cough is a very troublesome symptom that suffers patients a lot.

According to unani concept it is the respiratory system involved in respiration to expel the ratubat (secretions) out from the body. It is also known as Surfa in Unani system (Majoosi 2010, Jurjani/ A. Khan 2010). Cough is also helpful in getting rid of infectious materials with the help of mucus from the airway, it should not be stopped (Majoosi).

Unani scholars also described the associated symptom with chronic cough like imbalance of temperament (Soi mizaj seida and Soi mizaj meadi) (Majoosi 2011, A.Khan2010), inflammation of mucus membrane of lungs. (Abu Masarul Hussan Qamsi 2007). Any new irritant which causes obstruction of lungs like smoke, dust, pollen, cold air ( Jurjani 2010/A. khan 2011/ Majoosi 2011).Gastro esophageal reflex disease is a common cause of chronic cough ( Goldsibel.etal 2011 March).

\section{Aim and Objectives:}


The aim of this study was to evaluate the action of Unani drugs Hab-e-Surfa and Sharbat-e-Unab in upper respiratory disorders. The evaluation of efficacy was based on symptomatic improvements

\section{MATERIALS AND METHOD}

An open label, uncontrolled clinical study was done on 60 patients with upper respiratory disorders were identified and registered in outpatient department of Regional Research Institute of Unani medicine, University of Kashmir Srinagar from September 2012-September 2015.

60 patients of both sexes in the age group of 14-60 years were selected for this study. All the cases were examined in detail and investigated at baseline and after completion of the study and the relevant findings were recorded in a proforma specially designed for this study, informed consent was obtained from all the patients (35 cases males and 25 cases of females).

Table 1: Shows distribution of Age and Sex

\begin{tabular}{llll}
\hline Age(Years) & Male & Female & Total no. of Patients \\
\hline $14-25$ & 6 & 3 & 9 \\
$26-35$ & 8 & 5 & 13 \\
$36-45$ & 15 & 9 & 24 \\
$46-55$ & 4 & 5 & 9 \\
Above 55 & 2 & 3 & 5 \\
Total & $\mathbf{3 5}$ & $\mathbf{2 5}$ & $\mathbf{6 0}$ \\
\hline
\end{tabular}

\section{Safety assessment:}

The safety of the drugs treatment was assessed through non-occurrence of any toxic or adverse effect during the treatment period (At base line and at the time of completion of therapy) on the following parameters: Complete Haemogram, KFT, LFT, Blood Sugar and X-ray.

\section{Efficacy assessment:}

The assessment of the efficacy was determined on the following parameters:

Subjective Parameters:

- Decrease in the cough

- Decrease in sputum expectoration

- Improvement in breathlessness
Decrease in stuffy nose

Improvement in sore throat

Improvement in hoarseness of voice.. etc.

The drug Hab-e-Surfa 2 tabs twice a day and Sharbat-e-Unab 2 tsf was administered twice daily for 1 week.

The following criteria were used for grading the response of Hab-e-Surfa and Sharbat-e-Unab.

Good: - $\quad$ Complete relief of symptoms of cough.

Fair: - $\quad$ Partial relief of cough bouts.

Poor: - $\quad$ No reliefs of symptoms of cough bouts. 


\section{Inclusion Criteria:}

- Age 14-50 (Sex both).

- Non-smokers for 10 years.

- Patient able to participate in the study and ready to follow the instructions and sign the consent form.

\section{Exclusion Criteria:}

- History of obvious inhaled irritant exposure.

- Evidence of primary or secondary immunodeficiency.

- Clinically important bronchiectasis on HRCT scan.

- Abnormal LFT's (greater than 2x upper limit of normal).

- Pregnancy or intent to become pregnant during course of study.

- Contra-indication to bronchoscopy (as per British Thoracic Society Guideline)

Table 2: (a) Ingredients of Sharbat-e-Unab

\begin{tabular}{lllll}
\hline S. No & Unani Name & Botanical Name & Quantity \\
\cline { 2 - 4 } & Unab & \multicolumn{4}{c}{ Zizyphus sativa 261 mg } & \\
\cline { 2 - 4 } & \multicolumn{4}{c}{ (b) Ingredients of Hab-e-Surfa } \\
& S. No & Unani Name & Botanical Name & Quantity \\
\hline 1 & Rubussoos & Glycyrrhizia glabra & $26.1 \mathrm{mg}$ \\
& 2 & Magz e Behidana & Cydonia oblonga & $26.1 \mathrm{mg}$ \\
\hline
\end{tabular}

Table 3: Presence of respiratory symptoms before treatment in both sexes

\begin{tabular}{llll}
\hline S. No & Symptoms & $\begin{array}{l}\text { No. of patients } \\
\text { ( Males) }\end{array}$ & $\begin{array}{l}\text { No. of patients } \\
\text { (Females) }\end{array}$ \\
\hline 1 & Dry Cough & 35 & 25 \\
2 & Stuffy nose & 30 & 25 \\
3 & Sore throat & 32 & 23 \\
4 & Hoarseness of voice & 35 & 20 \\
5 & Breathlessness & 21 & 22 \\
6 & Chest pain & 30 & 23 \\
7 & Insomnia & 25 & 20 \\
8 & Urinary incontinence & 7 & 21 \\
\hline
\end{tabular}




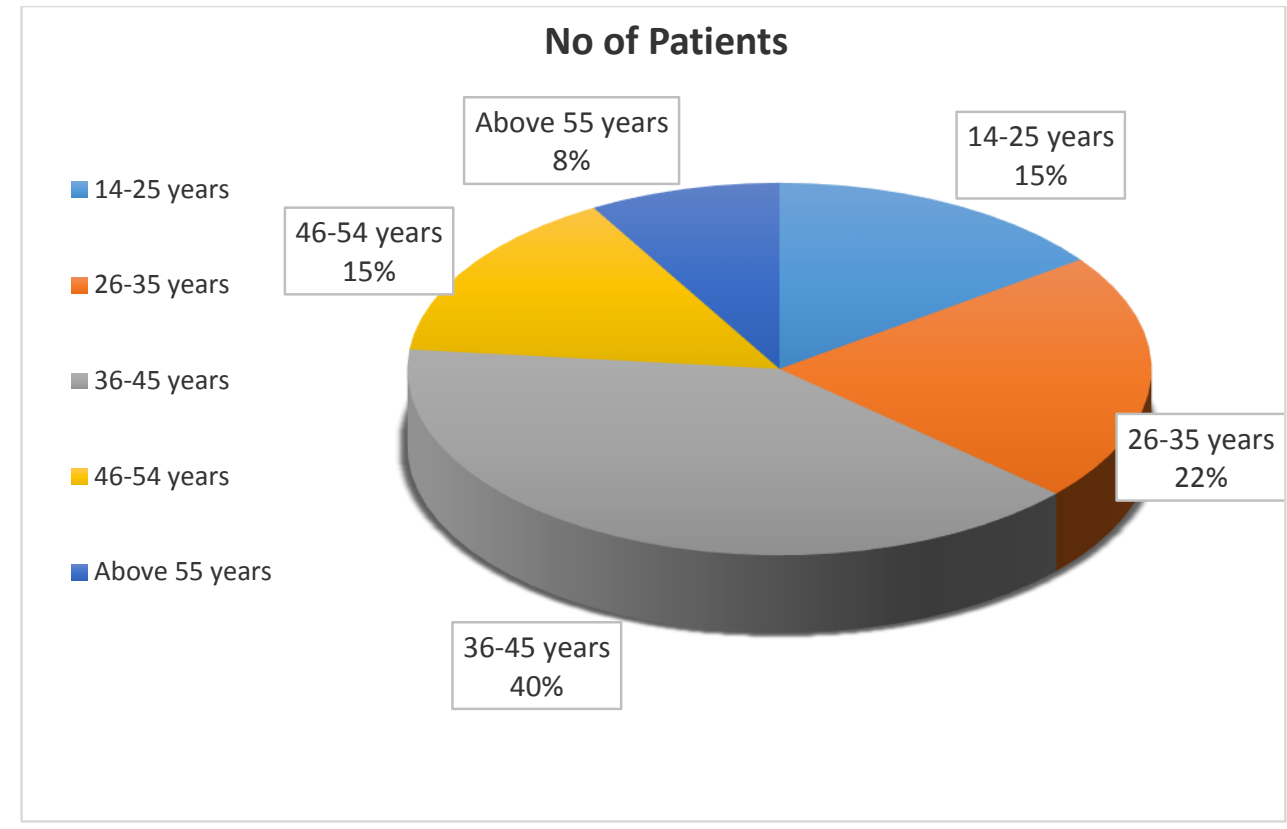

Graph: 1 Distribution of participant on the basis of age

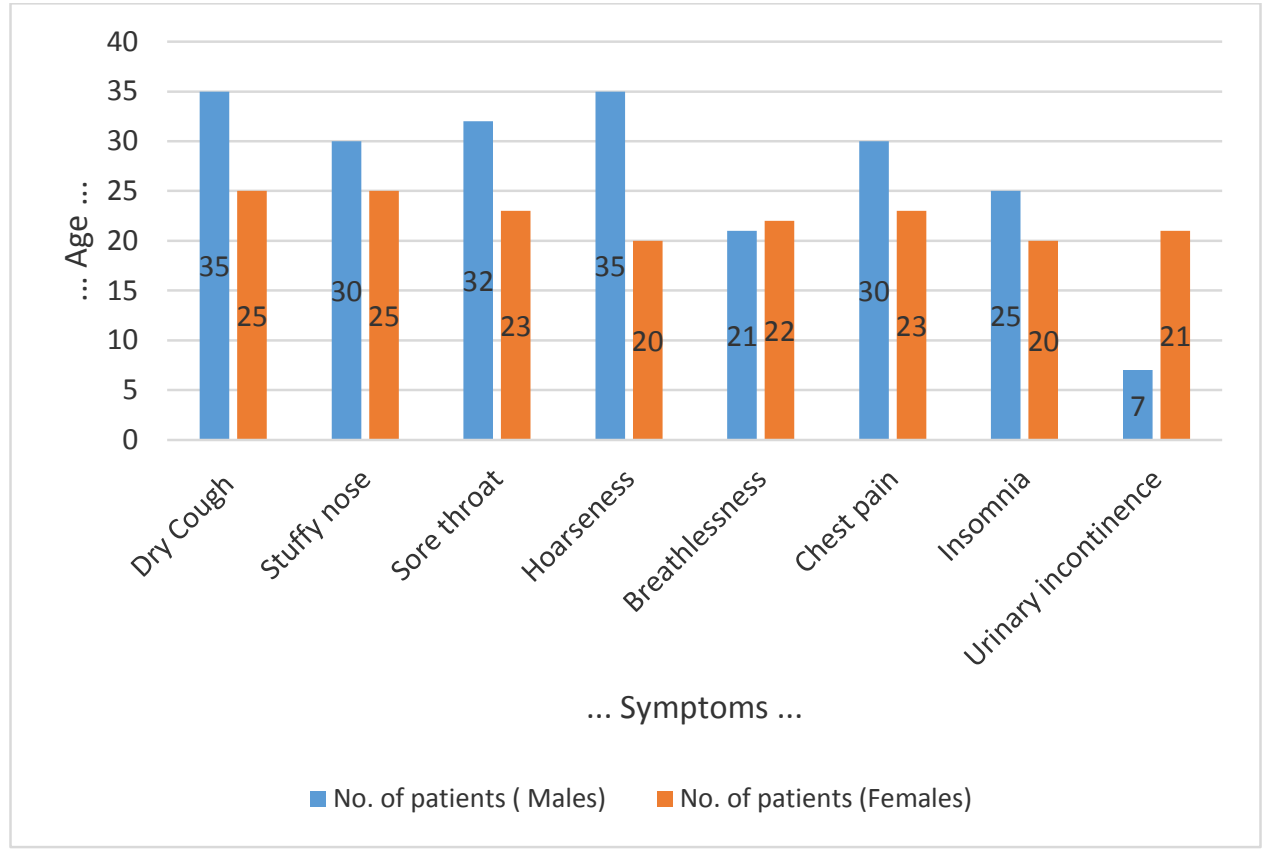

Graph-II: Presence of respiratory symptoms before treatment in both sexes

\section{Observation and Results:}

It was observed that the incidence of upper respiratory tract disorders was higher in age group between 36-45 years (Graph 1) and least common in the age group above 55 years. (Tab-2). The disease was found more common in males than in females ( 35 patients were males and 25 patients). Most of the patients had stuffy nose with chest pain, sore throat and hoarseness of voice (Table$3)$. 
Table 4. Improvement in symptoms before treatment and after treatment

\begin{tabular}{llllll}
\hline S. No & Symptoms & \multicolumn{2}{c}{ Males } & \multicolumn{2}{c}{ Females } \\
& & BT & AT & BT & AT \\
\hline 1 & Dry cough & 10 & 3 & 7 & 1 \\
2 & Stuff Nose & 15 & 3 & 10 & 2 \\
3 & Sore throat & 10 & 0 & 5 & 0 \\
4 & Hoarseness & 8 & 0 & 5 & 0 \\
5 & Insomnia & 10 & 2 & 7 & 2 \\
\hline
\end{tabular}

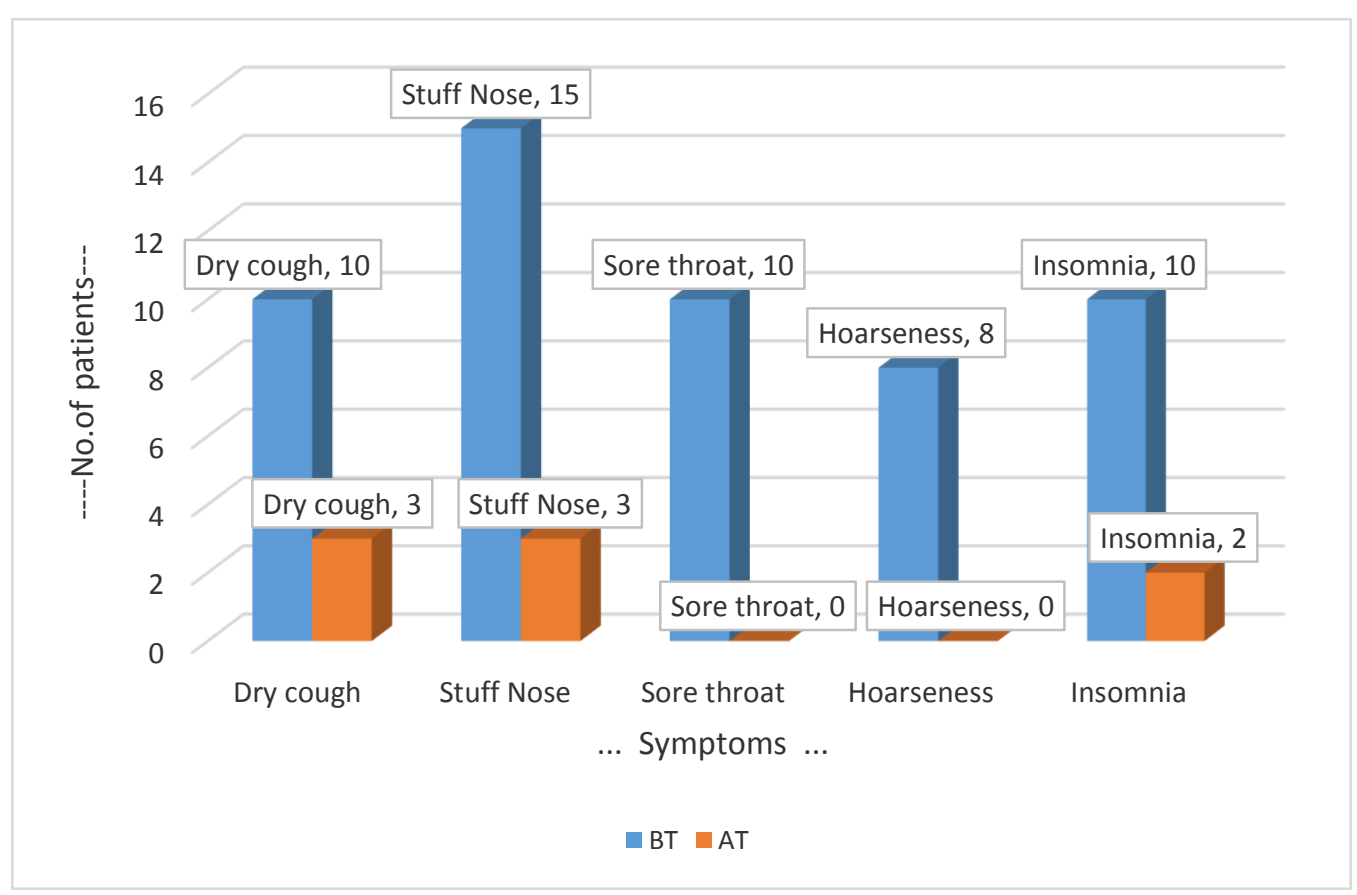

Graph -III: Improvement in symptoms after treatment in Males

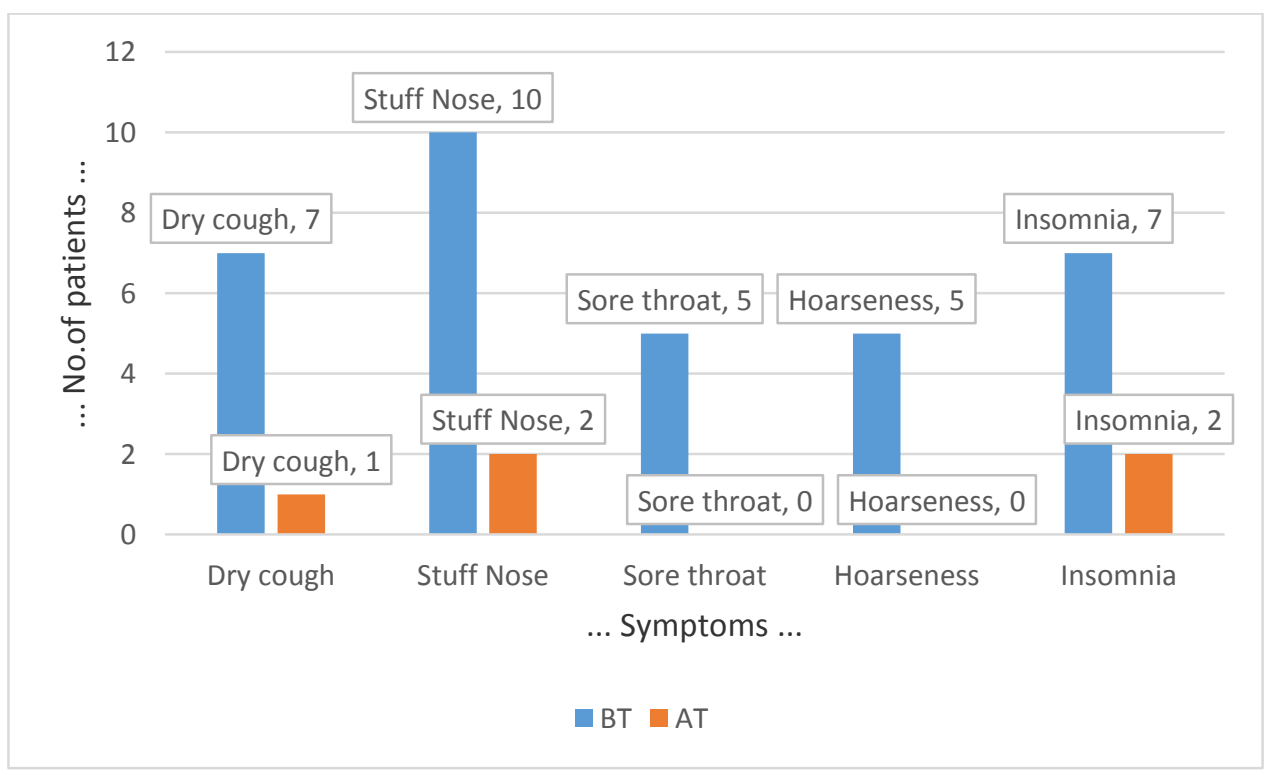

Graph IV: Improvement in symptoms after treatment in Females

Out of 60 patients, 47 were totally relieved, 13 patients reported moderate symptoms like cough in 4 patients, stuffy nose in 5 patients and Insomnia in 4 patients as shown in Graph III. 


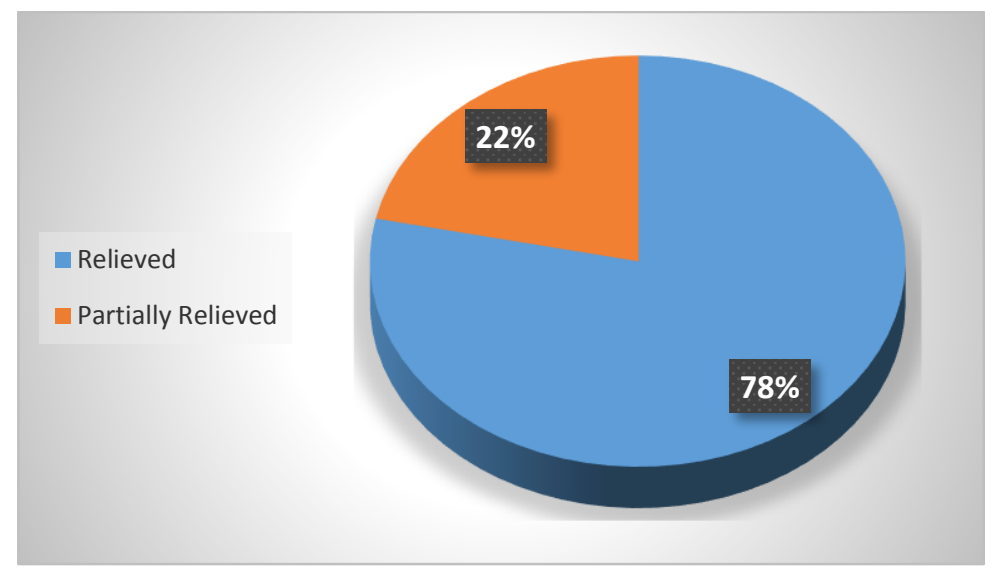

\section{DISCUSSION AND CONCLUSIONS}

The Common allergens like pollen, moulds spores and occupational allergens are responsible for Upper respiratory tract infections. Antihistamines are useful in controlling some of the symptoms but chances of recurrence are more. There are many Unani drugs used in upper Respiratory tract disorders but a significant improvement was seen in all the clinical parameters of upper respiratory tract disorders with the use of Hab-e-eSurfa and Sharbat -e-Unab. No adverse effect has been noticed during the study period. The ingredients of Hab-e- Surfa, Asal-u-soos is having efficacy of lubricant, expectorant, concoctive and thermogenic. (Hkm Abdul Hafeez 2005), Behidana acts as expectorant, coolant, sedative, lubricant and febrifuge (Hkm Saif ud Din Ali 1997, Farah Ahmad etal.2005). Unab acts as Analgesic, Coolant, Demulcent, concoctive and blood purifier also (Hkm Naseer Ahmed Tariq 2004, Hkm Gh. Jeelani 1995). The drugs Hab-e-Surfa and Sharbat-e- Unab given in patients having upper respiratory disorders are having good results. (Table-4)

Thus it is concluded that this study indicates the significant results of Hab-e-Surfa and Sharbat-eUnab in the management of upper respiratory tract disorders.

\section{REFERENCES:}

1. Abul MansorulHassan (2007) Minhajul illaj P.no.128-130 CCRUM New Delhi

2. Aazam Khan (2011), Alseer-azam, P.no. 269-273, Kitabul-Shifa, New Delhi

3. Canning, B.J. et al (2004), Identification of tracheal and laryngeal afferent neurosis mediating cough in anesthetized guinea pigs. J.Physol P. no. 543,558

4. E.C.Warner 1998 Savills system of clinical medicine-P.no.130,160-161.CBS Publishers and distributers Shadra Delhi

5. Farah, Qudisia Nizami, M. Aslam, (2005) Classification of Unani drugs Maktaba Eshaatul Quran 4159 Urdu Bazar Jamia Masjid Delhi-6 P.no. 21, 57, 110, 162,164,202,214, 236, 238,256 .

6. Goldsibel. etal.(2010) Cough in Pediatric Population, P. no 352-358 
7. Hkm. Abdul Hafeez (2005). Qarababdin Jadeed CCRUM New Delhi pp 128.

8. Hkm.Syed Saif -u-din Ali (1997) Unani Adviyat Mufiridat, National council for promotion of Urdu language New Delhi, west block R.K.Purum.

9. Hkm Naseer Ahmed Tariq (2004), Tajul- Mufaridat Houzul- Adiviyat. Idara kitabul Shifa 2075. Kucha chalan, Darya Ganj. New Delhi. P.no. 501-502.

10. Hkm. Gh. Jeelani khan (1995). Kitabul Murakabat, Mukarazin wa Murakabat. Aijaz publishing house 2060. Kucha chalan Darya Ganj New Delhi. P.no. 201, 218.

11. Irfat Ara, M Iqbal, Syed Basharat Bukhari, Nighat Ara, Indian Journal of Unani Research Vol. 3, Issue 3, July 2012 ,P.no. 22-33.

12. Irfat Ara, Seema Akbar, Mohammad Naime, Syed Basharat Bukhari, Response of Herbal Medicine to the Withdrawal of Bronchodilators and Corticosteroids in Bronchial Asthma (Zeequn Nafas) Patients International Journal of Advanced Ayurveda, Yoga, Unani, Siddha and Homeopathy 2015, Volume 4, Issue 1, pp. 235-242.

13. Irwin R S. etall (1990) Chronic Persistent cough in the adult revive Respiratory diseases P.no.141 (3).

14. Jurjani, M. Ismail (2010) Zakhira Kh wariz Shahi (Urdu translation) Vol-II. P.no 264-268. Kitabul-Shifa, New Delhi.

15. Janson.C. etal (1991) Determination of cough in young adults participating in the European community respiratory health survey. P.no. 647-654(18).

16. Kabir ud din (2007) Sharah Asbab.Vol-I, P.no. 1-11. Aijaz Publishing House, New Delhi.

17. Majoosi, Ali bin Abas (2010) Kamil-al-Sanaah, Vol-V, P. no 489-492. Central Council for Research in Unani Medicine, New Delhi.

18. Mazzone.SB (2003) Sensory pathways for the cough reflex on cough causes mechanism and therapy. P. no. 160-171.

AJPHR is

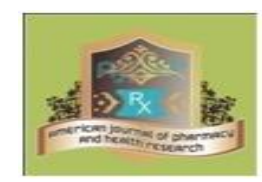

Peer-reviewed

monthly

Rapid publication

Submit your next manuscript at

editor@ajphr.com / editor.ajphr@gmail.com 